\title{
SUSTAINABILITY THOUGHTS 114: HOW CAN THE HIDDEN UNEQUAL NATURE OF THE SCIENCE BASED LIBERAL DEMOCRACY MODEL AND THE HIDDEN UNEQUAL NATURE OF THE LIBERAL MARKET MODEL BE LINKED? WHAT ARE THE IMPLICATIONS OF THIS?
}

\author{
Lucio Muñoz* \\ * Independent qualitative comparative researcher/consultant, Vancouver, BC, Canada
}

http://doi.org/10.35409/IJBMER.2020.3214

\begin{abstract}
The unequal nature of the science based liberal democracy model tells us that in reality individuals and groups of individuals received unequal access to government support. While the unequal nature of the liberal market model says that in reality individuals and groups of individuals received unequal access to economic growth. These two models mentioned above do not work parallel to each other as at the heart of science based liberal democracies there is a liberal market; and therefore, they are linked. And this raises the question, how can the hidden unequal nature of the science based liberal democracy model and the hidden unequal nature of the liberal market model be linked? What are the implications of this?
\end{abstract}

KeywordLiberal democracy, Liberal market, sustainability, equality, inequality, trickledown, trickle up, pro-rich support, pro-poor support, pro-rich growth, pro-poor growth, balanced support, unbalanced support, balanced growth, unbalanced growth,

\section{INTRODUCTION}

a) The unequal nature of the science based liberal democracy model

The unequal nature of the science based liberal democracy model tells us that in reality individuals and groups of individuals received unequal access to government support, a situation summarized graphically recently(Muñoz 2020a) as indicated in Figure 1 below: 
International Journal of Business Management and Economic Review

Vol. 3, No. 06; 2020

ISSN: 2581-4664

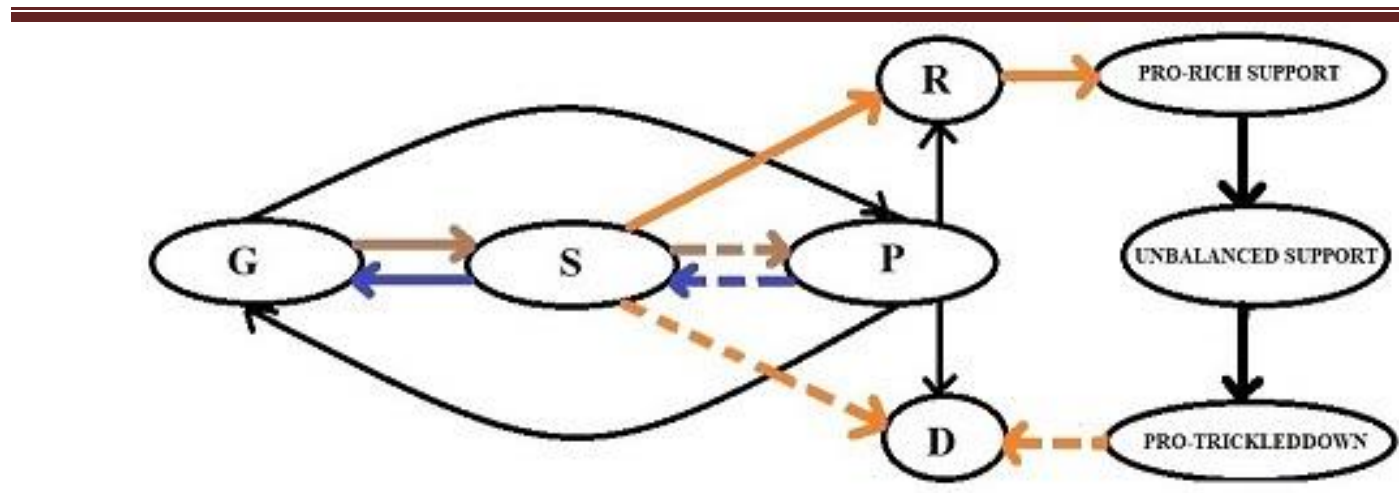

Figure 1 Science based liberal democracy under group support imequality

The model in Figure 1 above is the science based liberal democracy model(SLDM) under inequality, which tells us the following things: i) that the government $(\mathrm{G})$ is elected by the people $(\mathrm{P})$ as indicated by the black arrows going from $P$ to $G$ and from $G$ to $P$, yet the government $(\mathrm{G})$ uses science $(\mathrm{S})$ to provide unequal support to the people $(\mathrm{P})$ by focusing its attention on supporting the rich $(\mathrm{R})$ as indicated by the arrow from $\mathrm{S}$ to $\mathrm{R}$ and leaving the poor $(\mathrm{P})$ out of direct support programs as indicated by the broken arrow from $\mathrm{S}$ to $\mathrm{D}$; ii) that any increase in government $(\mathrm{G})$ support accrues to the rich $(\mathrm{R})$ through pro-rich support programs that lead to unbalanced support development; iii) that to justify that the poor(D) are left out of direct support programs as indicated by the broken arrow from $\mathrm{S}$ to $\mathrm{D}$ the government is counting on or assuming pro-rich support trickling downs to help the poor(D), but indirect support never reaches the poor(D) as indicated by the broken arrow from pro-trickledown to D; and iv) that the poor(D) is expected to thrive without direct support from the government(D) and without indirect support from the rich(R). It is known that access to institutions or government support in developing countries is linked to political, economic, and social inequities present there(Jones 2009), but the same access inequities should be expected in developed countries.

Notice that the structure of the model in Figure 1 above is the structure of an imperfect science based liberal democracy model(ISLDM) as it operates under permanent support inequality routes separating the rich(R) and the poor(D) creating this way permanent inequality fissures located between the rich(R) and the poor(D). Under those inequality conditions we should expect support to follow the rich/supply side route as pro-rich support(Muñoz 2010), support inequality that should be expected to go even more extreme when democracies tend towards full amorality(Muñoz 2019). In the science based democracy model in Figure 1 above it is okay to leave some people or groups behind in terms of support.

\section{Expectation 1:}

Given Figure 1 above, we should expect that any support response to external threats that affect the survival of the rich(R) in that structure of the science based liberal democracy mode(SLDM) will be channeled or disbursed following those permanent support inequality routes increasing that way the size of the support inequality fissure, except when the treat is a binding threat to the survival of the $\operatorname{rich}(\mathrm{R})$ : When facing a binding threat to its survival the rich $(\mathrm{R})$ should be expected to endorse direct trickle downs in help to the poor(D) as that is needed to survive as it 


\section{International Journal of Business Management and Economic Review}

Vol. 3, No. 06; 2020

ISSN: 2581-4664

cannot disentangle from a binding threat. For example, with bipartisan support The United States approved financial support this march(Cochrane and Fandos 2020) for businesses(direct trickle up) and for workers and the unemployed(direct trickledown) in response to the corona virus threat. However, even when under a binding threat the flow of support from the science based liberal democracy model should be expected to tend to the rich(R) first and faster than the flow of support to the poor(D). For example, in the USA money available to support businesses run outs very quick as they have quick access to the stimulus(Simon and Rudegeair 2020) while money allocated to help the workforce is still there as access for those who lost their jobs and the unemployed is difficult(Singletary 2020) and/or slow(BBC 2020).

\section{b) The unequal nature of the liberal market model}

The unequal nature of the liberal market model says that in reality individuals and groups of individuals received unequal access to economic growth, a world shared recently graphically(Muñoz 2020b) as detailed in Figure 2 below:

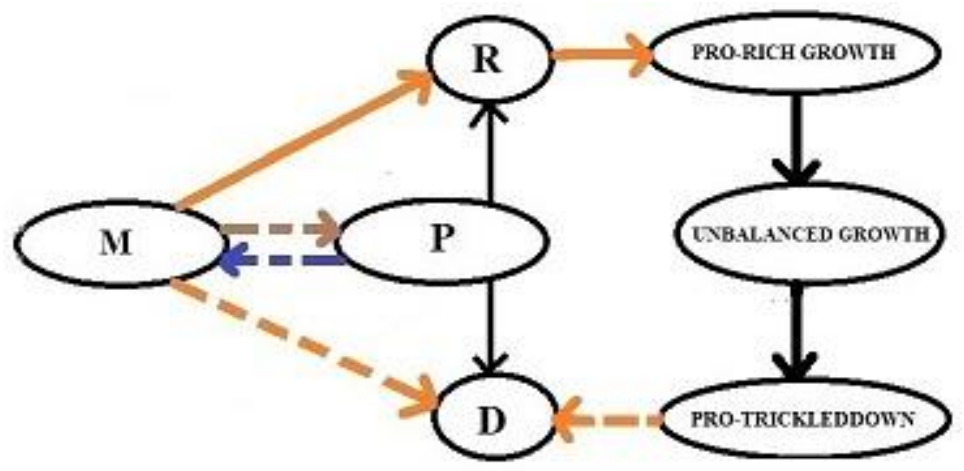

Figure 2 Markets under group growth inequality

The model in Figure 2 above is the liberal market model under inequality, which indicates the following things: i) that the market(M) provides unequal benefits to the people(P) by focusing its attention on supporting the $\operatorname{rich}(\mathrm{R})$ as indicated by the arrow from $\mathrm{M}$ to $\mathrm{R}$ and leaving the poor $(\mathrm{P})$ out of direct benefit programs as indicated by the broken arrow from $\mathrm{M}$ to $\mathrm{D}$; ii) that any increase in market benefits accrues to the rich(R) through pro-rich growth programs that lead to unbalanced economic development; iii) that to justify that the poor(D) are left out of direct benefit programs as indicated by the broken arrow from $\mathrm{M}$ to $\mathrm{D}$ the market is counting on or assuming pro-rich growth trickling downs to benefit the poor(D), but indirect benefits never reach the poor(D) as indicated by the broken arrow from pro-trickledown to $\mathrm{D}$; and iv) that the poor(D) is expected to thrive without direct benefits from the market(M) and without indirect benefits from the rich(R). It is known that inequalities lead to unequal development(IMF 2011) and that there is a need then to keep in check pro-rich growth by advancing ideas like inclusive growth(OECD 2018) aimed at both promoting pro-poor growth institutional building(WB 2003) as well pro-poor growth policy actions(OECD 2007).

Notice that the structure of the model in Figure 2 above is the structure of an imperfect liberal market model(ILMM) as it operates under permanent benefit inequality routes separating the 
International Journal of Business Management and Economic Review

Vol. 3, No. 06; 2020

ISSN: 2581-4664

$\operatorname{rich}(\mathrm{R})$ and the poor(D) creating this way permanent inequality fissures located between the $\operatorname{rich}(\mathrm{R})$ and the poor(D). Under those inequality conditions we should expect market benefits to follow the rich/supply side route as pro-rich growth following the embudoeffect(Muñoz 2009), market benefit inequality that should be expected to go even more extreme when democracies tend towards extreme liberal democracies(Muñoz 2017) like USEXIT. For example, the 2017 tax cut to the rich in The United States that was approved by the US Senate was sold as something that was going to trickledown benefits to workers and the poor(CBC 2017), but no trickledown has taken place (Hendricks et al 2019). In the market model in Figure 2 above it is okay to leave some people or groups behind in terms of benefits.

\section{Expectation 2:}

Given Figure 2 above, we should expect that any benefit response to external threats that affect the survival of the rich(R) in that structure of the liberal market mode(LMM) will be channeled or disbursed following those permanent benefit inequality routes increasing that way the size of the benefit inequality fissure, except when the treat is a binding threat to the survival of the rich(R): When facing a binding threat to its survival the rich(R) should be expected to endorse direct trickle downs in benefits to the poor(D) as that is needed to survive as it cannot disentangle from a binding threat. For example, the recent stimulus package again corona virus attack had full multi-party approval in Canada(Bolongaro 2020), all political groups, pro-rich, pro-poor and pro-middle class endorsed the package. However, even when under a binding threat the flow of benefits from the liberal market model should be expected to tend to the $\operatorname{rich}(\mathrm{R})$ first and faster than the flow of benefits to the poor(D). For example, while Canada put forward a huge stimulus package to support businesses and individuals to fight the corona virus(Alexander 2020), qualifying for help for workers and students is confusing(Molko 2020), and they need to reapply each month during the period the help is available bringing more uncertainty in the access to help. These benefit or support access inequality routes exist in the liberal market model since the time of Adam Smith(Smith 1776), inequalities that scientists and decision-makers are trying to fix since 1987(WCED 1987) to the 2012 shift to green market thinking(UNCSD 2012a: UNCSD 2012b) to the current use of externality management approaches like carbon pricing(GC 2019). The economic inequalities existing at local and global contexts, which are strongly affecting the pace of progress in development at those levels are well-known(WB 2006; OECD 2019).

(c) The need to understand the link between sciences based liberal democracy and the liberal market world under inequality

These two models mentioned above do not work parallel to each other as at the heart of science based liberal democracies there is a liberal market; and therefore, they are linked. And this raises the question, how can the hidden unequal nature of the science based liberal democracy model and the hidden unequal nature of the liberal market model be linked? What are the implications of this?

\section{Goals of this paper}

(a) to show how the science based liberal democracy model and the liberal market model can be linked; and b) To highlight the implications of this in terms of how government action is linked 
International Journal of Business Management and Economic Review

Vol. 3, No. 06; 2020

ISSN: 2581-4664

to science based unequal economic treatment of individuals and groups of individuals.

\section{Methodology}

(i) the terminology used in this paper is shared; ii) some operational concepts are given; iii) the science based liberal democracy model and the liberal market model are linked; iv) the implications of living in a economic science based liberal democracy under inequality are stressed; and v) some food for thoughts and conclusions are provided.

\section{Terminology}

ISLDM = imperfect science based liberal democracy $\quad S=$ science IESLDM = imperfect economic science based liberal democracy $\mathrm{P}=$ people $\mathrm{SM}=$ economic science based market $\quad \mathrm{R}=$ the rich/supply side of the market $\mathrm{D}=$ the poor/the demand side of the market $\quad \mathrm{LDM}=$ liberal democracy model $\mathrm{G}=$ elected government one person-one vote $\mathrm{M}=$ Liberal market

\section{Operational concepts}

\section{a) Liberal market}

1) Equality, the idea that all members of a system receive the same treatment.

2) Inequality, the idea that only some members of a system receive better treatment.

3) The liberal market, the pro-growth market.

4) Sustainability, the idea that equality in treatment leads to full responsibility.

5) Trickledown, the idea that pro-rich growth will one day indirectly benefit the poor.

6) Direct trickledown, the help that reach the poor directly.

7) Extreme intervention based direct trickle down, the government help that reach the poor directly during an extreme event.

8) Trickle up, the government help that reach the rich directly during an extreme event.

9) Indirect trickle up, the idea that direct trickledown will benefit pro-rich growth.

10) Pro-rich growth, the type of development targeted to benefits the rich.

11) Pro-poor growth, the type of development targeted to benefit the poor.

12) Balanced growth, the type of development that brings benefits to both the rich and the poor at the same time.

13) Unbalanced growth, the type of development that brings benefits to only the rich or to only the poor.

14) Externality neutrality assumption illusion, the idea that relevant inequalities or market distortions can be assumed away to create perfect conditions.

b) Liberal democracy

1) Equality, the idea that all members of a system receive the same support.

2) Inequality, the idea that only some members of a system receive better support.

3) The liberal democracy model, the one based on majority rule, one person, one vote.

4) Sustainability, the idea that equality in support leads to full responsibility.

5) Trickledown, the idea that pro-rich government support will one day indirectly benefit the poor. 
International Journal of Business Management and Economic Review

Vol. 3, No. 06; 2020

ISSN: 2581-4664

6) Direct trickledown, the support that reach the poor directly.

7) Extreme intervention based direct trickle down, the government support that reach the poor directly during an extreme event.

8) Trickle up, the government support that reach the rich directly during an extreme event.

9) Indirect trickle up, the idea that direct trickledown will benefit pro-rich support.

10) Pro-rich support, the type of support targeted to benefits the rich.

11) Pro-poor support, the type of support targeted to benefit the poor.

12) Balanced support, the type of support that brings benefits to both the rich and the poor at the same time.

13) Unbalanced support, the type of support that brings benefits to only the rich or to only the poor.

14) Externality neutrality assumption illusion, the idea that relevant inequalities or liberal democracy distortions can be assumed away to create perfect conditions.

\section{Linking the science based liberal democracy model and the liberal market world under inequality}

Notice that if the type of science(S) based model of the liberal democracy structure in Figure 1 above is based on economic science or the science of liberal markets(M) summarized in Figure 2 above that means that pro-rich support leads to pro-rich growth, which leads to unbalanced growth and which in turn leads to pro-trickledown expectations, so we can insert the structure in Figure 2 into Figure 1 as indicated in Figure 3 below:

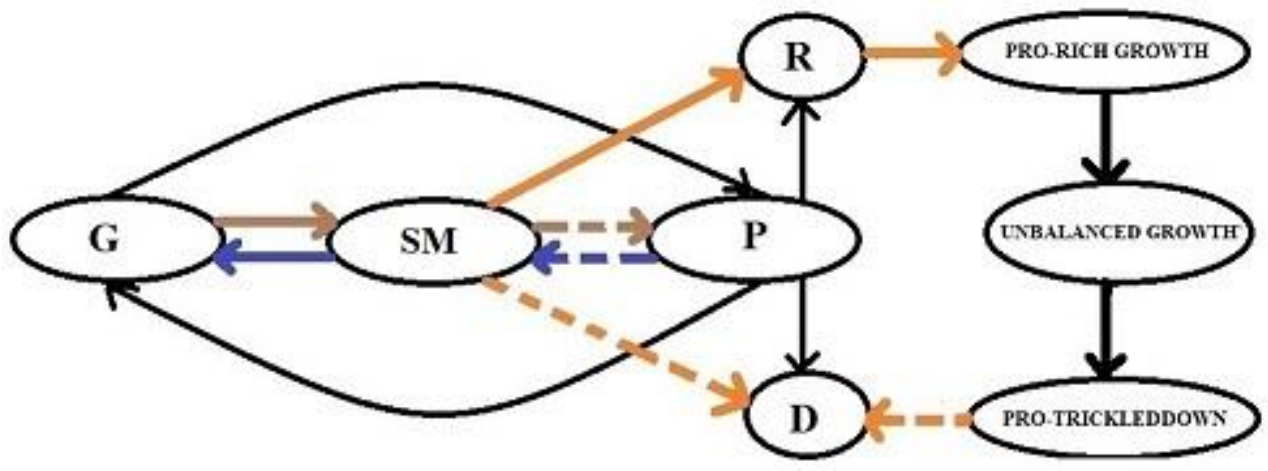

Figure 3 Linking science based democracy and liberal markets(SM) under inequality

The model in Figure 3 above is the economic science based liberal democracy model(ESLDM) under inequality, which says the following things: i) that the government $(\mathrm{G})$ is elected by the people $(\mathrm{P})$ as indicated by the black arrows going from $\mathrm{P}$ to $\mathrm{G}$ and from $\mathrm{G}$ to $\mathrm{P}$, yet the government $(\mathrm{G})$ uses economic science $(\mathrm{M})$ to provide unequal benefits to the people $(\mathrm{P})$ by focusing its attention on supporting the $\operatorname{rich}(\mathrm{R})$ as indicated by the arrow from $M$ to $R$ and leaving the poor $(\mathrm{P})$ out of direct benefit programs as indicated by the broken arrow from $\mathrm{M}$ to $\mathrm{D}$; ii) that any increase in government $(\mathrm{G})$ support or benefits accrues to the rich $(\mathrm{R})$ through pro-rich support programs that lead to unbalanced economic development; iii) that to justify that the poor(D) are left out of direct benefit programs as indicated by the broken arrow from $\mathrm{M}$ to $\mathrm{D}$ the 


\section{International Journal of Business Management and Economic Review}

Vol. 3, No. 06; 2020

ISSN: 2581-4664

government is counting on or assuming pro-rich benefit trickling downs to help the poor(D), but indirect benefits never reach the poor(D) as indicated by the broken arrow from pro-trickledown to $\mathrm{D}$; and iv) that the poor(D) is expected to thrive without direct benefits from the government(D) and without indirect benefits from the rich(R).

Notice that the structure of the model in Figure 3 above is the structure of an imperfect economic science based liberal democracy model(IESLDM) as it operates under permanent science based benefit inequality routes separating the $\operatorname{rich}(\mathrm{R})$ and the poor(D) creating this way permanent science based inequality fissures located between the rich(R) and the poor(D).

\section{Expectation 3:}

Given Figure 3 above, we should expect that any benefit response to external threats that affect the survival of the $\operatorname{rich}(\mathrm{R})$ in that structure of the economic science based liberal democracy model(ESLDM) will be channeled or disbursed following those permanent science based benefit inequality routes increasing that way the size of the science based benefit inequality fissure, except when the treat is a binding threat to the survival of the $\operatorname{rich}(\mathrm{R})$ : When facing a binding threat to its survival the rich(R) should be expected to endorse direct science based trickledowns in benefits to the poor(D) as that is needed to survive as it cannot disentangle from a binding threat. However, even when under a binding threat the flow of benefits from the economic science based liberal democracy model should be expected to tend to the rich $(R)$ first and faster than the flow of benefits to the poor(D).

\section{Implications}

(i)The current economic science based liberal democracy model(ESLDM) under which we live today detailed in Figure 3 above has the same structure as the economic science based liberal democracy model that existed in Adam Smith times, a model thriving under inequalities; and hence, the only way Adam Smith could have stated a perfect traditional market model as he did in 1776 was by assuming a world under a total inequality neutrality assumption; and ii) regardless of whether the threat of external threats to the well-being of the rich is binding or not, the poor will be at the back end of any benefit response program aimed at counteracting the economic impact of that external treat.

\section{Food for thoughts}

(i) Can market unsustainability lead to democracy unsustainability? I think yes, what do you think?; ii) Is a liberal democracy when acting without science shooting in the dark? I think yes, what do you think?; iii) Is an imperfect economic science based liberal democracy action the solution to a pandemic response? I think no, what do you think?; and iv) Should we expect the fear of a pandemic trickle up lead to supply side support for direct trickle downs to the demand side of the market? I think yes, what do you think?

\section{CONCLUSIONS}

First, it was pointed out how the science based liberal democracy model can be linked to the current liberal market model under inequality to arrive to the economic science based liberal democracy model in which we currently live in. Second, it was stressed how elected governments use this economic science based liberal democracy model to perpetuate group 


\section{International Journal of Business Management and Economic Review}

Vol. 3, No. 06; 2020

ISSN: 2581-4664

benefit inequalities and benefit fissures. Third, it was highlighted that the only way an unequal model by design can be found to be a perfect model is by total inequality neutrality assumptions. Finally, it was highlighted when facing external threats the economic science based liberal democracy model under inequality should be expected to leave the poor last when implementing even extreme benefit responses to binding threats to the wellbeing of the rich.

\section{REFERENCES}

Alexander, Craig, 2020. Canada deploys large fiscal stimulus, more to come, March 18, Deloitte Canada, Toronto, ON, Canada.

Bolongaro, Kait, 2020. Trudeau Wins Opposition Backing for $\$ 57$ Billion Virus Aid Package,Politics, March 25, Bloomberg, New York, NY, USA.

British Broadcasting Corporation(BBC), 2020. Coronavirus: US pushes direct payment plan as part of \$1tn stimulus, Business News, March 17, London, UK.

Canadian Broadcasting Corporation(CBC), 2017.U.S. Senate approves major tax cuts in legislative win for Trump, News, World, December 02, Toronto, ON, Canada.

Cochrane, Emily and Nicholas Fandos, 2020.Senate Approves \$2 Trillion Stimulus After Bipartisan Deal, Politics, March 25, The New York Times, New York, NY, USA.

Government of Canada(GC), 2019. How we're putting a price on carbon pollution, Ottawa, ON, Canada.

Hendricks, Galen, Seth Hanlon and Michael Madowitz, 2019. Trump's Corporate Tax Cut Is Not Trickling Down, Economy, September 26, Center for American Progress, Washington, DC, USA.

International Monetary Fund(IMF), 2011. All for One: Why inequality throws us off balance, Finance and Development, September, Vol. 48, No. 3, Washington, DC, USA.

Jones, Harry, 2009. Equity in development: Why it is important and how to achieve it, Working Paper 311, November, Overseas Development Institute, London, UK.

Molko, David, 2020. Confused about applying for the CERB? You're not alone, April 21, CTV News, Vancouver, BC, Canada.

Muñoz, Lucio, 2009. How Do Agricultural Development Benefits Actually Spread: Is it the Trickle Down Effect or the Embudo Effect? In: Environment and Society, Special Edition, No. 372, January 8, ECOPORTAL, Buenos Aires, Argentina.

Muñoz, Lucio, 2010. Where Should Donors Place Their Monetary and Trade Incentives to Encourage Developing Countries to Implement Balanced Pro-Rich/Pro-Poor Development Programs?, Journal of Sustainability, Issue 3, Number 2(Fall), Rio Rancho, New Mexico USA. Muñoz, Lucio, 2017. Upside Down Democratic Outcomes: Stating the Complacency Conditions Under Which Extreme Democratic Outcomes Such as BREXIT and USEXIT Should Be Expected to Take Place Using Qualitative Comparative Means. Boletín CEBEMREDESMA, Año 10, No. 9, December, La Paz, Bolivia.

Muñoz, Lucio, 2019. Moral and Amoral Liberal Democracies: How Targeted Chaos Can Affect the Democratic Process?, In: International Journal of Management Studies and Social Science Research(IJMSSSR), Volume 1, Issue 2, March-April, Ed. Dr.VishalMuvel, India.

Muñoz, Lucio, 2020a .Sustainability thoughts 113: How can the hidden unequal nature of 
International Journal of Business Management and Economic Review

Vol. 3, No. 06; 2020

ISSN: 2581-4664

the liberal democracy model be detailed step by step?,Boletin CEBEM-REDESMA, Año 14, No.5, May, La Paz, Bolivia.

Muñoz, Lucio, 2020b.Sustainability thoughts 112: How can the hidden unequal nature of the liberal market model be detailed step by step?, Boletin CEBEM-REDESMA, Año 14, No.4, April, La Paz, Bolivia.

Organisation for Economic Cooperation and Development(OECD), 2007. Promoting Pro-Poor Growth POLICY GUIDANCE FOR DONORS,DAC Guidelines and Reference Series, Paris, France.

Organisation for Economic Cooperation and Development(OECD), 2018. FRAMEWORK FOR POLICY ACTION ON INCLUSIVE GROWTH, Meeting of the OECD Council at Ministerial Level, May 30-31Paris, France.

Organization for Economic Cooperation and Development(OECD), 2019. BEYOND GROWTH: TOWARDS A NEW ECONOMIC APPROACH: Report of the Secretary General's Advisory Group on a New Growth Narrative, September 12, Paris, France.

Simon, Ruth and Peter Rudegeair, 2020.Big Banks Favor Certain Customers in \$350 Billion Small-Business Loan Program, Markets, April 6, The Wall Street Journal, New York, NY, USA.

Singletary, Michellem, 2020. Stimulus check glitches: Why you're having trouble and what you can do about it, Personal Finance, April 18, The Washington Post, Washington, DC, USA.

Smith, Adam, 1776. The Wealth of Nations, W. Strahan and T. Cadell, London, UK.

United Nations Conference on Sustainable Development(UNCSD), 2012a. Rio+20 Concludes with Big Package of Commitments for Action and Agreement by World Leaders on Path for a Sustainable Future, Press Release, June 20-22, New York, NY, USA.

United Nations Conference on Sustainable Development(UNCSD), 2012b. The Future We Want, June 20-22, New York, NY, USA.

World Bank(WB), 2003. Toward Pro-Poor Policies Aid, Institutions, and Globalization, $5^{\text {th }}$ Annual World Bank Conference on Development Economics Europe: Economic Integration and Social Responsibility, Paris, France, May 15-16, Washington DC, USA.

World Bank(WB), 2006. World Development Report: Equity and Development, Copublication with Oxford University Press, Washington, DC, USA.

World Commission on Environment and Development(WCED), 1987. Our Common Future, Oxford University Press, London, UK. 